\title{
The determinants of Sustainable Corporate Performance at PT. GCR Textile
}

\author{
Yanti $^{1}$, Lenny C Nawangsari ${ }^{2}$ \\ $\left\{\right.$ y2kamei1309@gmail.com ${ }^{1}$, lenny.christina@mercubuana.ac.id $\left.{ }^{2}\right\}$
}

Universitas Mercu Buana, Jakarta, Indonesia ${ }^{12}$

\begin{abstract}
Both industrialization and globalization provide a positive impact on economic growth but they, on the other hand, are also a major cause of environmental damage. To avoid this environmental damage, every company in its operation is required to focus on the environment-friendly concept to achieve sustainable corporate performance. The purpose of the article is to examine and analyze the influence of Green Transformational Leadership, and Green Training Variables on Sustainable Corporate Performance at PT. GCR Textile through the Employee Green Behavior as the mediating variable. The research method was a quantitative approach with a causal exploration design. The sample of this study was 90 respondents who use a simple random sampling technique. Data collection techniques using a questionnaire instrument with a Likert scale measurement. Data were then analyzed by using SEM PLS Smart PLS Software version 3.2.8. The results of this study indicate that the independent variable has directly a significant effect on sustainable corporate performance also through its mediating variable employee green behavior. The author recommends that management should improve pro-environment leadership, equal training opportunities, and recruitment for pro-environment employees.
\end{abstract}

Keywords: Green transformational leadership, Green training, Employee green behavior, Sustainable corporate performance

\section{Introduction}

Environmental damage is caused by business activities then it increases the pressure on business people because they are required to carry out CSR programs through environmentally friendly processes and products. Through law number 32, in 2009, the Indonesian government requires all companies should participate to protect the natural environment as a part of the company output. Also, within Bandung Regional Regulation number 02 of 2014 was regulated the management and control of hazardous and toxic waste, especially for textile and paper companies, because their waste also contributes to the Citarum river. Carrying out operational activities textile companies are required to protect the environment through activities such as environment-friendly production processes, waste management, pollution control systems, waste recycling, and environmental release mitigation, which aims to create a sustainable performance.

According to the leadership of PT. GCR Textile through a brief interview, in Bandung said that Sustainable corporate performance is strongly influenced by the Employee green behavior or environmentally friendly behavior of HR. GHRM practices are needed to create friendly environment human resources, which will support the organization to support to 
achieve sustainability programs, especially for green training. GHRM is a special program to create vision, mission, values, and SME strategy to enhance business growth and sustainability [1]. One important thing in achieving a company's sustainable performance is leadership. A leader determines efficiency in achieving the company's vision, mission, and main company's objectives. The success and continuity of an organization depend on the strength/weaknesses of leadership because the leader must be the controller of the direction that is to be taken by an organization [2].

To find out any longer about the influence of Green transformational leadership and Green training on Employee green behavior and Sustainable corporate performance, researchers then surveyed 30 employees at PT. GCR Textile is a research sample where results show that sustainable company performance which has decreased is influenced by green transformational leadership that has not been maximized in becoming a green role model for employees, green training that has not been evenly distributed and has not been able to shape the green behavior of employees in the company. It can be seen from the results of the Employee green behavior assessment that it is not yet in line with the company's target. Based on the description of the problems above, researchers are interested in examining whether the variable Green transformational leadership and Green training affect the Employee green behavior and Sustainable corporate performance at PT. GCR Textile?

The following is a theoretical background of the variables studied, including:

a. Green transformational leadership

Pro-environmental transformational leadership [2] is "a manifestation of transformational leadership, in which the contents of leadership behavior are focused on supporting environmental initiatives". A transformational leader who has green values will influence the green behavior of his subordinates (green idealized influence), where he will motivate subordinates to overcome obstacles by paying more attention to things that are beneficial to the organization's environment (green inspirational motivation), think about sustainable organizational development, and solve environmental problems in more innovative ways (green intellectual stimulation) and create close relationships with employees to influence their environmental performance (individualized consideration/green individualized consideration).

b. Green training

Green training \& development is training that educates and trains employees to master the work methods that saves energy, reduces waste, has environmental awareness in organizations, and provides opportunities to involve employees in solving environmental problems [5]. Indicators in measuring an organization's green training are the number of training, training opportunities, quality of training, effectiveness, and evaluation of training $[5]$.

c. Employee green behavior

Understanding Employee Green Behavior (EGB) is a behavior that is intentionally carried out to reduce the negative impact of human resource actions on the environment and this behavior is scaled according to the context of the job assignments that are required by employees and it contributes to environmental sustainability such as organizational policies, changing work methods and creating a product through an ongoing process [7]. EGB can be in the form of activities such as saving energy, using resources efficiently, avoiding waste, recycling, and saving water [8]. There are five broad functional categories of EGB, ie: efficiency, task control, environment care, motivation, and intention to positive behavior [9]. 
d. Sustainable corporate performance

Sustainable corporate performance [10] is a performance that can be achieved on condition that companies must consider to reduce environmental footprints and start paying attention to social, environmental, economic, and financial factors to succeed in the corporate sector. Furthermore, it enables the achievement of profits by shareholders. The company's sustainability performance is measured when there is an efficient use of resources, increasing cost advantages, reducing waste and disposal, and promotion. Environmental performance is known from social reputation, improved customer preferences, and the generation of new innovative capabilities [11].

The study of theory and empirical studies state the relationship between the variables of Green transformational leadership, Green training, Employee green behavior, and Sustainable corporate performance in the following conceptual framework diagram:

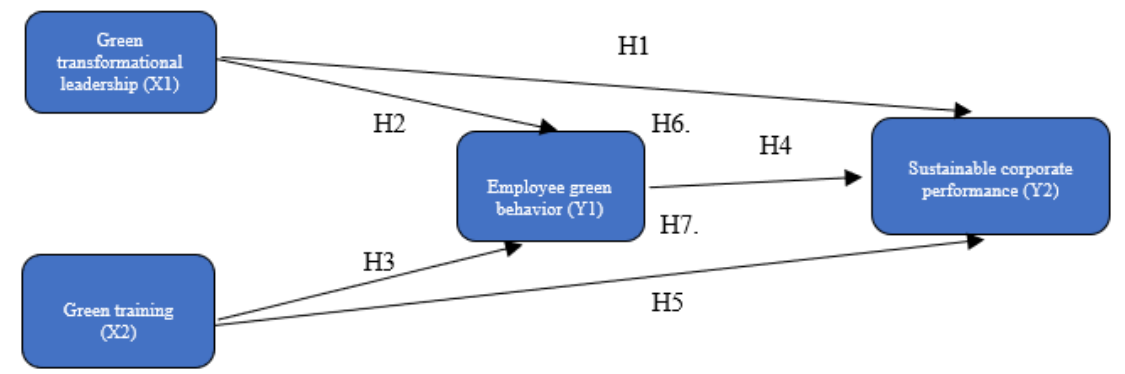

Hypothesis:

Fig 1. Conceptual Framework

H1: Green transformational leadership has a positive and significant effect on Sustainable corporate performance

H2: Green transformational leadership has a positive and significant effect on Employee green behavior

H3: Employee green behavior has a positive and significant effect on Sustainable corporate performance

H4: Green training has a positive and significant effect on Employee green behavior

H5: Green training has a positive and significant effect on Sustainable corporate performance.

H6: Green transformational leadership has a positive and significant effect on Sustainable corporate performance with Employee green behavior as a mediating variable

H7: Green training has a positive and significant effect on Sustainable corporate performance with Employee green behavior as a mediating variable.

Based on theoretical background above and previous research, it was explained that Green transformational leadership has positive relation to the appropriateness of employee perception values and significantly influences employees' environment-friendly behavior [3] and ultimately influences the performance of sustainability companies [4]. Green training can change employees' values, behavior, and attitudes to achieve sustainable competitive advantage [6]. 


\section{Research Method}

This type of research is quantitative research, about which the analysis of data in the form of numbers as a tool to find the information we want to know. This research is a causal explorative study, which is to explore data and information about the topic under study and aim to explain one or more factors that cause problems[12]. The population in this study were all employees of PT. GCR Textile number of 820 people. The sample determination by using the Slovin formula with an error tolerance of $10 \%$ because there is population homogeneity in terms of competence and educational background. So, the sample size will be studied including in 90 respondents. Data collection techniques employ a questionnaire instrument with a Likert scale measurement. The data analysis method employs SEM or Structural Equation Modeling to test hypotheses and produce a viable model, and data processing uses Partial Least Square (SmartPLS) software program version 3.2.8.

\section{Research Results}

\subsection{Outer model Testing}

The outer model defines the relationship of each indicator with its latent variables with the Confirmatory Factor Analysis (CFA) technique done through validity and reliability testing. Convergent validity is testing the validity of each construct indicator. An indicator is considered good valid if the loading factor value is greater than 0.70 , loading factor 0.50 0.60 can be adequately considered [13].

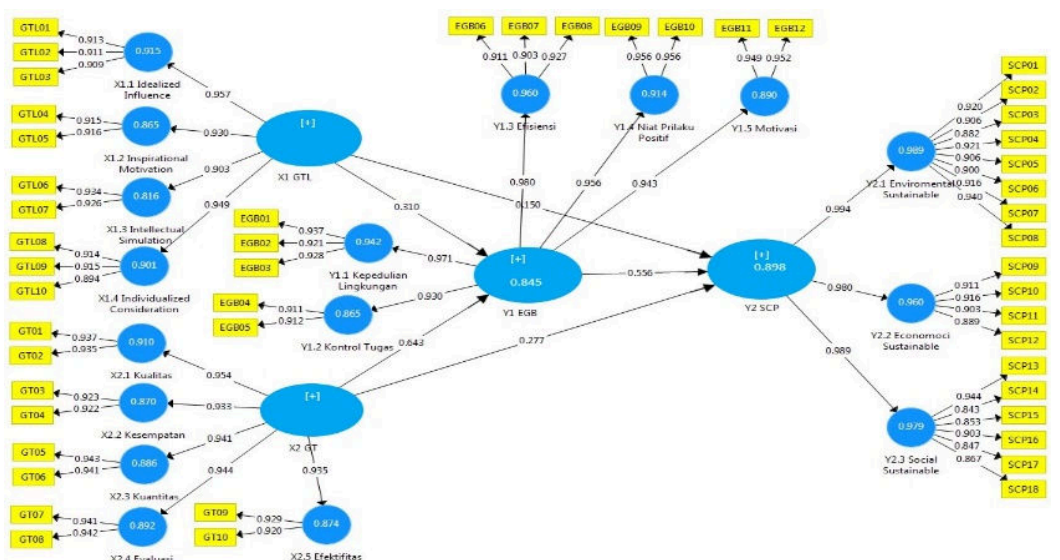

Fig 2. Testing the outer model

Based on Figure 2 it shows that the loading value of the indicator factors of all variables is greater than 0.70 , so it can be concluded that all indicator variables used in this study are valid or meet with convergent validity. The second stage of validity testing is the discriminant validity test by looking at the AVE value, if the AVE value is above 0.5 , it is considered valid. For each, each indicator block, Indicator Reliability Test is determined from the composite reliability and Cronbach's alpha. Rule of thumb alpha value or composite reliability must be greater than 0.7 though the value 0.6 is still acceptable. 
Table 1. AVE (Average Variance Extracted) and Value of Composite Reliability of the Research Model

\begin{tabular}{|l|c|}
\hline \multicolumn{1}{|c|}{ Variable } & $\begin{array}{c}\text { AVE } \\
\text { Value }\end{array}$ \\
\hline Green Transformasional Leadership (XI) & 0,737 \\
\hline Green Training (X2) & 0,772 \\
\hline Employee Green Behavior (YI) & 0,797 \\
\hline Sustainable Corporate Performance (Y2) & 0,791 \\
\hline
\end{tabular}

\begin{tabular}{|l|c|c|c|}
\hline \multicolumn{1}{|c|}{ Variabel } & $\begin{array}{c}\text { Composite } \\
\text { Reliability }\end{array}$ & $\begin{array}{c}\text { Crombach's } \\
\text { Alpha }\end{array}$ & Information \\
\hline Green Transformasional Leadership $(X I)$ & 0,965 & 0,960 & Relliable \\
\hline Green Training $(X 2)$ & 0,971 & 0,967 & Reliable \\
\hline Employee Green Behaviar $(Y I)$ & 0,979 & 0,977 & Reliable \\
\hline Sustainable Corparate Performance (Y2) & 0,985 & 0,984 & Relliable \\
\hline
\end{tabular}

Source: Analysis Results using SmartPLS 3.2.8

From the data in table 1, we can see the AVE value of all the variables above 0.5. Thus, while the Discriminant validity test has been fulfilled this research model is valid. Learned from table 2 we can conclude that the model meets with the Composite Reliability and Cronbach's Alpha criteria so that it meets with the reliability criteria and it is a reliable and reliable measuring tool.

\subsection{Inner Model Testing}

Testing with aims to measure how far the ability of the model in explaining the variance of the dependent variable is done by looking at the coefficient of determination. The coefficient of determination value is between zero and one. The criteria for limiting the value of $\mathrm{R}^{2}$ in three classifications are $\mathrm{R}^{2}=0.67,0.33$, and 0.19 as substantial, moderate, and weak.

Table 2. R Square Value $\left(\mathrm{R}^{2}\right)$ of the Research Model

\begin{tabular}{|l|c|c|}
\hline \multicolumn{1}{|c|}{ Constructs } & $\boldsymbol{R}$ Square & $\begin{array}{c}\boldsymbol{R} \text { Square } \\
\text { Adjusted }\end{array}$ \\
\hline Employee Green Behavior & 0,846 & 0,843 \\
\hline Sustainable Corporate Performance & 0,899 & 0,895 \\
\hline
\end{tabular}

Table 3 shows the relationships between constructs based on the R-square Adjusted value that the Employee Green Behavior variable (Y1) is 0.843 , which shows that $84.3 \%$ of the Employee Green Behavior (Y1) that can be influenced by the Green Transformational Leadership variable (X1), and Green Training (X2), while the remaining $15.7 \%$ is influenced by other variables outside the study.

\begin{tabular}{|c|c|c|c|c|c|c|}
\hline 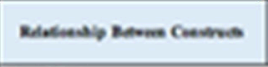 & 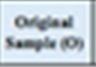 & Shank 10 & 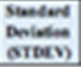 & $\begin{array}{l}\text { T Sutida } \\
\text { cosritev }\end{array}$ & Pvateo & hatirastes \\
\hline \multicolumn{7}{|l|}{ Domet rent } \\
\hline 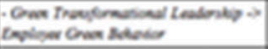 & 0.200 & ases & 0,000 & 2,as? & Q.00t & 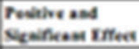 \\
\hline 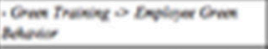 & 0.04 & ast & 0,000 & 2,202 & 2000 & 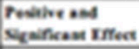 \\
\hline 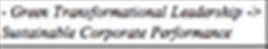 & 0.109 & 0.191 & 0,006 & 2206 & $\cos$ & 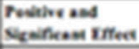 \\
\hline 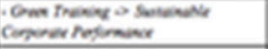 & a.2s & 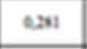 & a,on & 203 & exes & 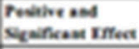 \\
\hline 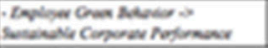 & 0.586 & 200 & Q,103 & us & 0,000 & 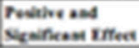 \\
\hline \multicolumn{7}{|l|}{ tedirm tinnes } \\
\hline 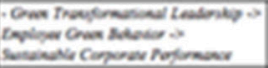 & $a, n$ & 2,69 & 0,050 & $2.20 t$ & 0,004 & 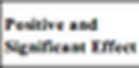 \\
\hline 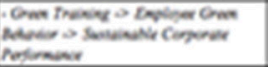 & $a s$ & ass & $\operatorname{ans}$ & $\omega 8$ & 0,000 & 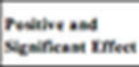 \\
\hline
\end{tabular}

Table 3. Path Coefficient, t-Statistics, and P-Values values

While the value of the R-square Adjusted variable Sustainable Corporate Performance (Y2) is 0.895 , which shows that $89.5 \%$ of the variable Sustainable Corporate Performance (Y2) can be influenced by the Green Transformational Leadership variable (X1), Green 
Training (X2), and the Employee Green Behavior variable (Y1), while the remaining 10.5\% is influenced by other variables outside the study.

\subsection{The Effect of Green transformational leadership on Employee green behavior}

Green transformational leadership has a positive and significant effect on Employee green behavior. Green transformational leadership positively influences the appropriateness of employee perception values and significantly influences employees' environment-friendly behavior[3]. Green transformational leadership talks about the way how leaders influence their subordinates to have environment-friendly behavior, expressed in the form of behavior or personality patterns. Such leadership plays a role as a dynamic force that can encourage, motivate, and coordinate the company to achieve its stated goals[14].

If the leader has a strong belief and vision and mission regarding the importance of green environment and sustainability, he or she will be able to influence employees in green behavior both within the company and the surrounding environment, especially in improving employee's efficient work with green behavior. Implementation of Green transformational leadership in PT. GCR Textile seen in the weekly meeting activity, the manager will conduct a review of the work of each employee related to their performance in the week both the output target in the form of products and processes, especially about waste management.

\subsection{The effect of Green training on Employee green behavior.}

Green training has a positive and significant effect on Employee green behavior. Green training is an important environment-friendly practice and can significantly enhance green behavior such as increasing employee awareness and knowledge about environmental issues, building up a positive attitude, taking a proactive approach to environmental problems that occur around them[15]. Green training which is usually held at PT. GCR Textile in the form of training on procedures in the production process aimed at increasing environment-friendly behavior especially regarding products that have been produced and the use of resources, for example, it is more efficient in terms of using fuels such as electricity, coal, chemicals, and produced products also become more environmentally friendly

\section{5 effect of Employee green behavior on Sustainable corporate performance.}

Employee green behavior has a positive and significant effect on Sustainable corporate performance In previous studies, it was found that there was a positive and direct relationship between EGB on organizational sustainability concerned to environmental sustainability that is if employees have green behavior he or she will tend to support the company to achieve sustainable corporate performance [16]. Employees care for the environment can be the attitude of employees who pay attention to the situation of the environment around them and try to help and improve the situation by preserving the environment such as helping to conserve resources and reduce waste in the production process. Green behavior in PT. GCR Textile we can see as routine employee assessments such as work behavior by rules or operational standards in the company, also support the company in achieving Sustainable corporate performance.

\subsection{The effect of Green Transformational leadership on Sustainable corporate performance.}

Green transformational leadership has a positive and significant effect on Sustainable corporate performance. This result is supported by previous research which says that in the 
process of achieving company performance sustainability it requires environmental-specific transformational leadership [17]. To achieve a sustainable company performance PT. GCR Textile is aware that there needs to be a commitment from top management and all levels of employees regarding environment-friendly behavior. PT. GCR Textile has a mission to be an environmentally friendly company, so it is hoped that leadership within the company could always encourage, motivate and guide every employee in green behavior and sustainable performance by paying attention to the surrounding environment.

\subsection{The effect of Green Training on Sustainable corporate performance}

Green transformational leadership has a positive and significant effect on Sustainable corporate performance. The results of this hypothesis are supported by previous research which says that GRHM is very influential on OCBE and SCP especially training because through green training a normal employee is educated and directed to be a green employee so that it can finally improve the green performance of employees and will contribute significantly to the sustainable corporate performance[18]. Training with qualified topics and good training methods will improve the company's sustainability, especially something related to the environment. The topic of environment friendly (green) must be the main topic in every training program that is routinely carried out by the company to improve sustainable performance.

3.8 The influence of Green Transformational leadership on Sustainable corporate performance through Employee green behavior

Green transformational leadership has a positive and significant effect on Sustainable corporate performance through Employee green Behavior. The results of this study are supported by previous research, which is said Green transformational leadership can change and improve employees' perceptions and green behaviors so that it helps improve the performance of sustainable companies[17]. Leadership which becomes a role model in green behavior, can influence, guide, support and always motivate employees to behave in an environment-friendly manner that will change and improve the behavior of employees who work under them so that in the end it is sure to affect further the company's sustainable performance or Sustainable corporate performance. Every PT's leader in Green behavior. PT. GCR Textile has always been a benchmark for every employee to behave. If a leader behaves in a green manner, subordinates will take part in behaving in a green manner and ultimately can improve the company's sustainable performance.

\subsection{The influence of Green Transformational leadership on Sustainable corporate performance through Employee green behavior}

Green transformational leadership has a positive and significant effect on sustainable corporate performance through employee green behavior. The results of this study are supported by previous research which says that GHRM, especially training is very important to change employee values, behavior, and attitudes to achieve sustainable competitive advantage and sustainable company performance[6]. Green training at PT. GCR Textile which involves all employees is expected to be able to increase employee awareness of the surrounding environment and change employee behavior so that in the end they will contribute to the company's sustainable performance concerned to 3P (profit, people, and the planet) [19]. 


\section{Conclusions}

The study conclusion is the variables Green transformational leadership and Green training affect positively and significantly on Employee green behavior and Sustainable corporate performance at PT. GCR Textile. It suggests that organizations should focus on improving employees' green behavior through leadership, training, and adding reward programs. The recruitment program points must include in terms of environment-friendly behavior and the character of environmental care as one of the tests in employee recruitment. Companies need to bear exemplary leaders in environment-friendly behavior through training and seminars.

Companies must pay more attention to employee training needs both in quality and quantity. It is suggested that further research test the conceptual framework in other manufacturing business organizations and services, to increase the contribution of knowledge, especially on improving the company's sustainable performance.

\section{References}

[1] L. C. Nawangsari and A. H. Sutawidjaya, "How the Green Human Resources Management (GHRM) Process Can Be Adopted for the Organization Business?," vol. 65, no. Icebef 2018, pp. 463-465, 2019, doi: 10.2991/icebef-18.2019.100.

[2] J. L. Robertson and E. Carleton, "Uncovering How and When Environmental Leadership Affects Employees' Voluntary Pro-environmental Behavior,” J. Leadersh. Organ. Stud., vol. 25, no. 2, pp. 197-210, 2018, doi: 10.1177/1548051817738940.

[3] X. Wang, K. Zhou, and W. Liu, "Value congruence: A study of green transformational leadership and employee green behavior," Front. Psychol., vol. 9, no. OCT, pp. 1-8, 2018, doi: 10.3389/fpsyg.2018.01946.

[4] W. Jiang, X. Zhao, and J. Ni, "The impact of transformational leadership on employee sustainable performance: The mediating role of organizational citizenship behavior," Sustain., vol. 9, no. 9, 2017, doi: 10.3390/su9091567.

[5] C. J. C. Jabbour, "Environmental training and environmental management maturity of Brazilian companies with ISO14001: Empirical evidence,” J. Clean. Prod., vol. 96, pp. 331338, 2015, doi: 10.1016/j.jclepro.2013.10.039.

[6] L. Almada and R. Borges, "Sustainable Competitive Advantage Needs Green Human Resource Practices: A Framework for Environmental Management," Rev. Adm. Contemp., vol. 22, no. 3, pp. 424-442, 2018, doi: 10.1590/1982-7849rac2018170345.

[7] S. Dilchert and D. S. Ones, "Environmental Sustainability in and of Organizations," Ind. Organ. Psychol., vol. 5, no. 4, pp. 503-511, 2012, doi: 10.1111/j.1754-9434.2012.01489.x.

[8] T. A. Norton, H. Zacher, and N. M. Ashkanasy, "Organisational sustainability policies and employee green behaviour: The mediating role of work climate perceptions," J. Environ. Psychol., vol. 38, pp. 49-54, 2014, doi: 10.1016/j.jenvp.2013.12.008.

[9] T. A. Norton, S. L. Parker, H. Zacher, and N. M. Ashkanasy, "Employee Green Behavior: A Theoretical Framework, Multilevel Review, and Future Research Agenda," Organ. Environ., vol. 28, no. 1, pp. 103-125, 2015, doi: 10.1177/1086026615575773.

[10] H. Fauzi, G. Svensson, and A. A. Rahman, "“Triple bottom line' as 'sustainable corporate performance': A proposition for the future,” Sustainability, vol. 2, no. 5, pp. 1345-1360, 2010, doi: $10.3390 /$ su2051345.

[11] C. Wijethilake, "Proactive sustainability strategy and corporate sustainability performance: The mediating effect of sustainability control systems," J. Environ. Manage., vol. 196, pp. 569-582, 2017, doi: 10.1016/j.jenvman.2017.03.057.

[12] U. Sekaran, "Metode Penelitian untuk Bisnis Pendekatan Pengembangan-Keahlian.," vol. Jakarta. S, 2017. 
[13] I. Ghozali, Struktural Equation Modeling Metode Alternatif dengan Partial Least Squares (PLS) dilengkapi Software Smartpls 3.0. Xlstat 2014 Dan Warpls, 4. 2014.

[14] L. M. Graves, J. Sarkis, and Q. Zhu, "How transformational leadership and employee motivation combine to predict employee proenvironmental behaviors in China," J. Environ. Psychol., vol. 35, pp. 81-91, 2013, doi: 10.1016/j.jenvp.2013.05.002.

[15] N. T. Pham, Z. Tučková, and Q. P. T. Phan, "Greening human resource management and employee commitment towards the environment: An interaction model," J. Bus. Econ. Manag., vol. 20, no. 3, pp. 446-465, 2019, doi: 10.3846/jbem.2019.9659.

[16] Q. Iqbal, S. H. Hassan, S. Akhtar, and S. Khan, "Employee's green behavior for environmental sustainability: a case of banking sector in Pakistan," World J. Sci. Technol. Sustain. Dev., vol. 15, no. 2, pp. 118-130, 2018, doi: 10.1108/wjstsd-08-2017-0025.

[17] J. Robertson, J. L., \& Barling, "Contrasting the nature and effects of environmentally-specific and general transformational leadershiptle," Leadersh. Organ. Dev. J., vol. 38, pp. 22-41.

[18] S. Alnajdawi, O. L. Emeagwali, and H. Elrehail, "The interplay among green human resource practices, organization citizenship behavior for environment and sustainable corporate performance: Evidence from Jordan,” J. Environ. Account. Manag., vol. 5, no. 3, pp. 171-184, 2017, doi: 10.5890/JEAM.2017.09.001.

[19] P. Mishra, "Green human resource management: A framework for sustainable organizational development in an emerging economy," Int. J. Organ. Anal., vol. 25, no. 5, pp. 762-788, 2017, doi: 10.1108/IJOA-11-2016-1079. 